\title{
EFFICIENCY AND PUNISHMENT IN A COORDINATION GAME: VOLUNTARY SANCTIONS IN THE MINIMUM EFFORT GAME
}

Fabrice Le Lec Ondřej Rydval Astrid Matthey

Charles University

Centerfor Economic Research and Graduate Education Academy of Sciences of the Czech Republic

Ec ono mics Institute
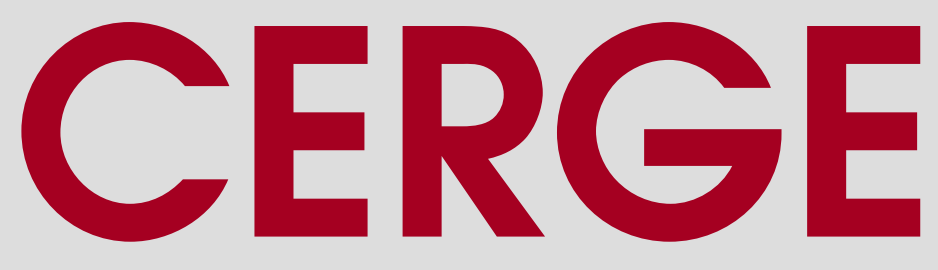


\section{Working Paper Series (ISSN 1211-3298)}

\section{Efficiency and Punishment in a Coordination Game: Voluntary Sanctions in the Minimum Effort Game}

Fabrice Le Lec

Ondřej Rydval

Astrid Matthey

CERGE-EI

Prague, December 2014 
ISBN 978-80-7343-331-4 (Univerzita Karlova. Centrum pro ekonomický výzkum a doktorské studium)

ISBN 978-80-7344-323-8 (Akademie věd České republiky. Národohospodářský ústav) 


\title{
Efficiency and Punishment in a Coordination Game \\ Voluntary Sanctions in the Minimum Effort Game
}

\author{
Fabrice Le Lec \\ Ondřej Rydval \\ and Astrid Matthey*
}

\begin{abstract}
Using a laboratory experiment, we examine whether voluntary monetary sanctions induce subjects to coordinate more efficiently in a repeated minimum effort coordination game. While most groups first experience inefficient coordination in a baseline treatment, the efficiency increases substantially once ex post sanctioning opportunities are introduced, that is, when one can assign costly punishment points to other group members in order to reduce their payoffs. We compare the effect of this voluntary punishment possibility with the effect of ex post costless communication: in contrast to the punishment treatment, the latter only temporarily increases efficiency and fails to do so permanently. This suggests that decentralized sanctions can play an important role as a coordination device in Pareto-ranked coordination settings, such as teamwork in firms and other organizational contexts.
\end{abstract}

Keywords: coordination, minimum effort, order-statistic game, punishment, sanction, weakest link

JEL classification: C72, C91, D01, D03

* Le Lec: Université Paris-1 Panthéon Sorbonne, Centre d'Economie de la Sorbonne UMR CNRS 8174, Maison des Sciences Economiques - 106-112 Boulevard de l'Hôpital - 75647 Paris cedex 13 France, fabrice.le-lec@univ-paris1.fr (corresponding author)

Matthey: German Federal Environment Agency, and Max Planck Institute of Economics, Jena, Germany, e-mail: astrid.matthey@uba.de

Rydval: CERGE-EI, a joint workplace of Charles University in Prague and the Economics Institute of the Academy of Sciences of the Czech Republic, Politickych veznu 7, 11121 Prague, Czech Republic, e-mail: ondrej.rydval@cerge-ei.cz. While working on this paper, Rydval was supported by the Czech Science Foundation grant P402/12/G130. 


\begin{abstract}
Abstrakt
S pomocí laboratorního experimentu zkoumáme, zda dobrovolné finanční sankce přimějí účastníky k efektivnější koordinaci v opakující se koordinační hře „minimum effort game”. Zatímco většina skupin nejprve prochází neefektivní koordinací v základní fázi („baseline treatment”), následné zavedení možnosti ex post sankcí (tj. možnosti přidělit ostatním členům skupiny body, a tím snížit jak jejich, tak částečně i vlastní výdělek) podstatně zvyšuje efektivitu koordinace. Pro porovnání ukazujeme, že nezávazná ex post komunikace, kdy přidělení bodů nemá finanční důsledky, zvyšuje efektivitu pouze dočasně. Naše poznatky naznačují, že decentralizované finanční sankce mohou být významným koordinačním mechanismem v oblastech vyznačujících se „Pareto-ranked” strukturou, jako je týmová práce ve firmách a jiných organizačních schematech.
\end{abstract}




\section{Introduction}

Coordination issues arise routinely in economic circumstances. In microeconomics, the ubiquity of coordination problems within firms, organizations and even industrial branches has been widely acknowledged (e.g., Becker and Murphy, 1992). One prominent game theoretic description of coordination issues is given by the minimum effort game, also known as the weakest-link game: a group member's payoff depends on her own effort (i.e., action) as well as the minimum effort of the group. The higher the minimum effort, the higher is every member's payoff. In contrast to social-dilemma games (e.g., public goods games), any common effort level chosen by all group members is an equilibrium, so it is in no one's interest to deviate upward or downward from the common effort. Hence choosing the most efficient (i.e., payoffdominant) equilibrium is a problem of coordination rather than one of cooperation. Many economic and organizational contexts feature situations where agents (e.g., group or team members) must coordinate on a common action with the group's success depending on the least favorable action of a team member. Among canonical examples are teams of assembly-line workers whose overall productivity depends on the least productive member, teams of construction workers whose ability to proceed to the next construction step hinges on every member having completed a task, law firm cases that are only as sound as their weakest part, and even collaboration on scientific projects. Camerer and Knez (1994) have underlined ways weakest-link coordination games can account for within-firm interactions.

Numerous experimental studies have been carried out to determine whether agents are able to collectively coordinate on efficient outcomes. For minimum effort games in particular, ample evidence from various contexts has documented a widespread failure to coordinate on the most efficient, or at least a highly efficient outcome on a long-term basis, starting with the seminal work of Van Huyck, Battalio, and Beil (1990). Various efficiency-enhancing features have been tested experimentally and several of those were found to partly achieve this goal. Among these are smaller groups (Van Huyck, Battalio, and Beil, 1990); higher incentives in the form of exogenous bonuses (Brandts and Cooper, 2007) or lower effort costs (Goeree and Holt, 2005); more refined action space (Van Huyck, Battalio, and Rankin, 2007); communication opportunities including pre-play cheap talk (Blume and Ortmann, 2007); 
ex post disapproval messages (Dugar, 2010) or centralized communication by a team leader (Brandts and Cooper, 2007); and more homogeneous socio-demographic group composition (Engelmann and Normann, 2010). Except in these very specific settings, there appears to be a gradual and pronounced failure to coordinate on the payoff-maximizing equilibrium, even when the stage game is repeated with the same subjects.

We turn to an alternative efficiency-enhancing device, namely voluntary monetary sanctions inflicted on group members who deviate from efficient coordination. Such a mechanism has been established as a powerful force to foster cooperation in public goods games (e.g., Fehr and Gaechter, 2000), suggesting that decentralized, informal sanctions might explain successful cooperation in the field (Ostrom, Walker, and Gardner, 1992). We hypothesize that a similar mechanism may be at work in coordination contexts. For instance, in team projects similar to the examples above, workers may have many opportunities to retaliate against low-effort individuals by not sharing strategic information, refusing future cooperation, and so forth. The sociological literature has long put forth that conventions and norms are often, if not always, enforced by individuals, most of the time in an informal, decentralized, and voluntary manner (Horwitz, 1990). The possibility of sanctions could thus have a strong effect on coordination dynamics as well as efficiency, potentially explaining high levels of efficient coordination in specific real-world settings.

To examine this hypothesis, we set up an experiment of the minimum effort game based on the work of Van Huyck, Battalio, and Beil (1990). At the beginning of each round, subjects in groups of eight choose an integer effort level between 1 and 7. Then subjects receive anonymous feedback on the effort choices of their fellow group members, and, depending on the treatment, can assign points to them. In the Disapproval treatment, these points simply act as a communication device signaling disapproval, with no monetary consequence, as tested by Dugar (2010). In the Punishment treatment, assigning the points imposes a fine on the punished group member, but also comes at a fee to the punisher, with the fine being twice as large as the fee. As in Masclet, Noussair, Tucker, and Villeval (2003), comparing the punishment and disapproval treatments allows us to disentangle what part of the punishment effect is due to implicit ex post communication, e.g., expression of disap- 
proval, and what is due to the monetary consequences of punishment per se. Even though intuitively appealing, it is not straightforward that subjects will use punishment in a coordination game. In contrast to a cooperation game, the individual motivation for punishment is less clear in coordination games where choosing low efforts penalize oneself to a certain extent. This makes it difficult to interpret such choices on the basis of purely selfish or malevolent intentions. Hence reciprocity, which has been found to be a powerful driver of such behavior (Falk, Fehr, and Fischbacher, 2008), does not necessarily lead to punishing behavior in such contexts. Whether punishment opportunities will be used in this context and whether they increase efficiency - in particular compared to mere disapproval communication opportunities - is the empirical question we aim to shed light on.

To provide an even stronger test, subjects in all treatments first complete eight rounds of play in the baseline minimum effort design without punishment, likely creating a history of low efficiency to be overcome in the next eight rounds with disapproval or punishment opportunities. A similar setup with an initial baseline phase has been used, for instance, by Brandts and Cooper (2006) to study the effect of ex ante communication; Romero (forthcoming) to examine variation in effort cost; and Fatas, Neugebauer, and Perote (2006) to assess the magnitude of a pure 'restart' effect between two successive identical baseline stages. Based on these studies, we expect to find strong path-dependence and, at best, a mild positive restart effect, hence facilitating a strong test of the viability of ex post monetary punishment and cheap-talk disapproval as coordination devices. This initial baseline stage distinguishes our Disapproval treatment from an otherwise similar disapproval treatment conducted in Dugar (2010). The purpose of our two-stage design is to assess more explicitly the efficiency-enhancing strength of punishment and disapproval by submitting the coordination devices to more adverse conditions. ${ }^{1}$

Our results show that, even after a history of coordination on inefficient equilibria, the possibility to punish others in the minimum effort game brings groups to (or very close to) Pareto-optimality in about a third of cases and considerably improves efficiency in another third of cases, even without much punishment being implemented.

\footnotetext{
${ }^{1}$ One may also interpret this as an investigation into whether, in a team exhibiting coordination failures, organizational changes that render punishment and disapproval possible have any positive effect, for instance a change in the availability of information regarding other team members' effort.
} 
By contrast, only temporary efficiency improvements are observed in the payoffneutral disapproval treatment, and only a very limited restart effect takes place in a baseline treatment without any communication or sanctioning device. This suggests that punishment provides a powerful coordination device, similar to its effect in public goods games, and superior to the effect of an ex post communication device alone.

The remainder of the paper is organized as follows. The next section presents the experimental design and procedures. Results are described in section 3, and discussed with some concluding remarks in the last section.

\section{Experiment}

The participants played 16 rounds of the minimum effort game, split into two stages of eight rounds each. At the beginning of the experiment, we handed out the instructions for the first stage and announced that there would be a second stage of unspecified nature (experimental instructions are available in the on-line Additional Material). Subjects also knew that only one of the two stages would be chosen at random to be paid.

In Stage 1, all the treatments featured a baseline design closely resembling the seminal one of Van Huyck et al. (1990). Groups consisting of eight players were formed randomly prior to the first round and remained the same for the entire experiment, this matching scheme being made known to the subjects. In each round, players simultaneously chose an integer effort level between 1 and 7. Each player's payoff depended on her effort choice and the lowest effort choice in her group. In particular, let $N=\{1,2,3, \ldots, 8\}$ be the group of players and $E=\{1,2, . ., 7\}$ be the set of effort levels, each player choosing effort $e_{i} \in E$. With $s=\left(e_{i}\right)_{i \in N}$ being the strategy profile of all players in the group, the payoff (in euros) of player $i$ in a given round is

$$
\pi_{i}\left(e_{i}\right)=0.4 \times \min _{j \in N}\left(e_{j}\right)-0.2 e_{i}+1.2
$$

Table 1 shows the corresponding payoff matrix. This payoff matrix with seven Pareto-ranked equilibria along the main diagonal was used with minor modifications 
by Van Huyck et al. (1990), Blume and Ortmann (2010), Dugar (2010) and many others.

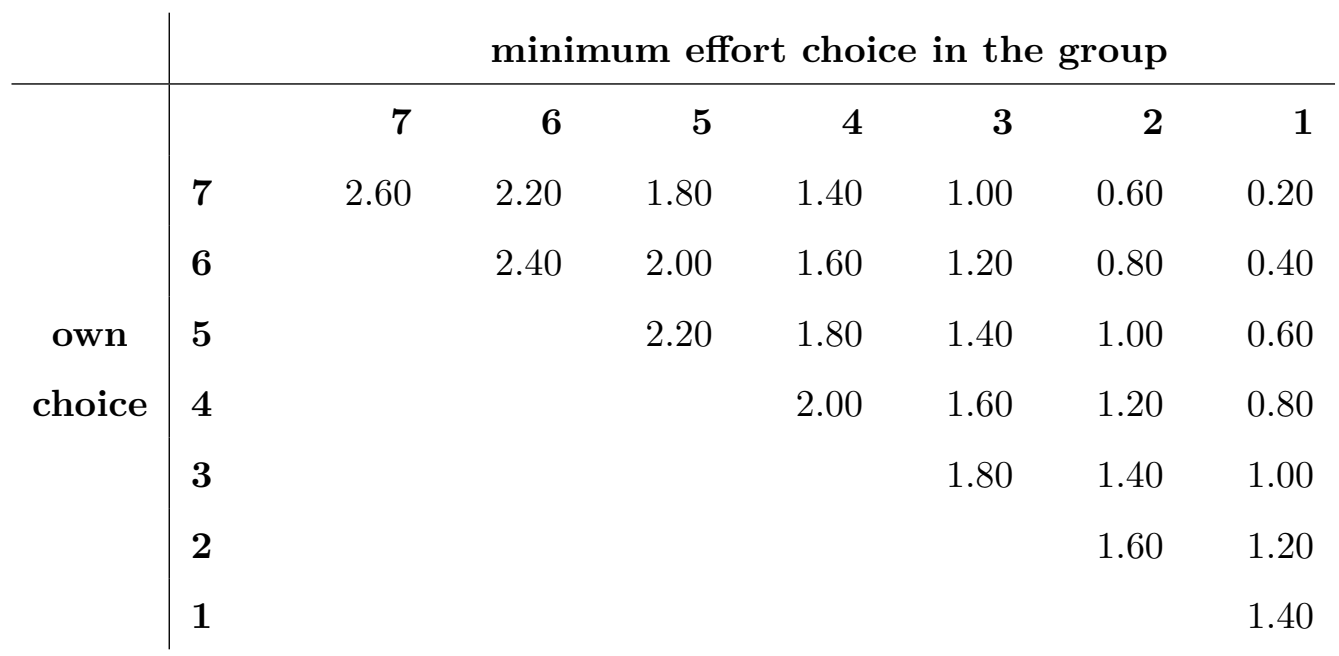

Table 1: Payoff matrix of the minimum effort game (in euros)

After all group members had made their effort choices, the feedback screen displayed the player's effort choice and payoff for the current round and her cumulative payoff for Stage 1. The same screen showed a table with the current effort choices and payoffs of fellow group members, ordered from the lowest to the highest effort. This feedback format closely resembles that used by Engelmann and Normann (2010) and Dugar (2010), and it constitutes the required feedback format applied in the subsequent Stage 2. for the subsequent Stage 2. A player's total payoff for Stage 1 consisted of the sum of her round payoffs plus an initial endowment of 4 euros.

After Stage 1, subjects received the instructions for Stage 2 in which the design differed across treatments. In the Baseline treatment, Stage 2 was identical to Stage 1. In the Punishment treatment, after receiving the feedback on effort choices and payoffs, subjects could (but were not required to) assign punishment points to fellow group members. Each point inflicted a cost of 10 cents on the punisher and 20 cents on the punished subject. After all players had assigned points, the feedback screen showed the sum and costs of points assigned by and to the subject in the current round, her resulting payoff for the current round, and her cumulative payoff for Stage 2. Since effort choices and payoffs of fellow group members were ordered from the 
lowest to the highest effort in each round and hence players' identity was concealed, "retaliation" or punishment of past effort choices was not possible. We chose this form of post-punishment feedback to parallel the one used in public goods games with punishment (e.g., Fehr and Gaechter, 2000, and Anderson and Putterman, 2006).

Punishment was limited by the punishing player's own cumulative payoff up to the previous round. In order to give players the opportunity to punish in the very first round of Stage 2 independently of their earnings in that round, subjects received an initial endowment of 4 euros. The endowment meant that a player with an effort choice of 7 facing seven other group members choosing effort level 1 was able to almost equalize the profit of all members in the first round (i.e., by assigning 6 points to each fellow group member). This ensures comparability between rounds and limits the effect of past earnings on punishment decisions. For reasons of symmetry, the 4 euro endowment was granted in both stages of all treatments.

The simultaneous choice of punishment points in any given round generates a second order public goods game where players may free-ride on others carrying out punishment. This problem is magnified by the fact that punishment points could only reduce other members' game payoff from the current round to zero at most, so some of the assigned points may be "wasted" in case they were to reduce her game payoff to below zero. While subjects of course did not know ex ante how many points other members would assign, the full cost of assigning points had to be born ex post. This results in a round payoff for player $i$ of

$$
\pi(s)_{\text {Punish }}=\max \left(0 ; 0.4 \min _{j \in N}\left\{e_{j}\right\}-0.2 e_{i}+1.20-0.2 \sum_{j \in N} P_{j i}\right)-0.1 \sum_{j \in N} P_{i j}
$$

where $P_{i j}$ denotes the punishment points that player $i$ assigns to player $j$.

To compare the effect of monetary and non-monetary sanctions, we ran a third treatment called Disapproval. The procedure in this treatment was as similar as possible to the one in Punishment, with the important difference that disapproval points did not inflict monetary costs on either the disapproving or the disapproved group member. The points were merely a means of communicating one's opinion 
about others' behavior. After receiving the feedback on effort choices and payoffs, a player could assign between zero and six points (only integer) to each other group member, with six points expressing the maximum disapproval. Thereafter, the displayed information matches the post-punishment feedback provided in the Punishment treatment. This differs slightly from the disapproval treatment in Dugar (2010) where subjects could in addition observe the sum of points assigned to their fellow group members. Other differences vis-a-vis Dugar's design are the number of group members and the number of rounds per stage - in both cases 8 in ours and 10 in Dugar's. Judged from the literature surveys of Devetag and Ortmann (2007) and Engelmann and Normann (2010), minor variation in these design features appears to have little or no (consistent) effect on coordination outcomes.

A likely more important design difference is the absence of Stage 1 in Dugar's experiment. There are at least two reasons for including the initial baseline Stage 1 in all our treatments. First, we wished to examine the effect of our treatment manipulation after a history of inefficient effort choices (anticipated on the basis of the findings of previous studies with similar design features), which arguably allows us to draw stronger conclusions regarding the hypothesized positive effect of monetary and non-monetary sanctions. The second reason for including Stage 1 is that it permits a difference-in-differences comparison of behavior across treatments. In other words, in addition to the standard contemporaneous across-treatment comparison of behavior in Stage 2, we are able to compare treatments in terms of between-stage changes in behavior, thereby accounting for across-treatment differences in groups' and individuals' initial propensity to coordinate efficiently.

Eight lab sessions of 32 subjects were run for a total of 256 subjects composing eight groups (2 sessions) for Baseline, 12 groups (3 sessions) for Disapproval, and 12 groups (3 sessions) for Punishment. ${ }^{2}$ The experiment was programmed and conducted in Z-Tree (Fischbacher, 2007) and lasted on average 80 minutes. Including a 2.50 euro show-up fee, the average earnings in the experiment were 18.18 euros (at that time around 24 USD), ranging between 7.10 and 27.30 euros. Participants were

\footnotetext{
${ }^{2}$ Another session was run with the baseline condition ( 32 subjects, 4 groups), but due to a technical problem the second stage of the experiment could not be run. The results of this session are not reported here, but are very similar to what is observed in the first stage of the experiment in all treatments.
} 
paid privately in cash, according to their performance. They were recruited among students of various disciplines at the local university using the ORSEE software (Greiner, 2004). In each session, gender composition was approximately balanced and each subject took part only in one session. In order to verify the subjects had understood the instructions, subjects were asked to answer several control questions. After all subjects had answered the questions correctly, the experiment started.

\section{Results}

We present the results along three main dimensions: the effect of Punishment, Disapproval and Baseline treatments, punishing and disapproving behavior, and the welfare effect of the treatments.

\subsection{Coordination and efficiency}

For each treatment, Figure 1 shows the evolution of average effort, and Figure 2 displays the evolution of average minimum effort (i.e., the average of groups' minimum effort). In Stage 1, both figures suggest little or no across-treatment differences. In all treatments, the average effort is initially around 5 and gradually falls to 2. Average minimum effort starts off at about 2 and does not diverge much from that level throughout the stage. At the end of the stage, the average effort is only marginally above the average minimum effort, which implies a low withingroup variance. Figure 3 presents a more disaggregate look at effort choices. In all treatments, the highest effort level is initially the most frequent choice and the lowest effort level is chosen by less than a tenth of subjects. Throughout Stage 1, effort-choice distributions in Baseline and Disapproval gradually polarize towards the highest and especially the lowest effort level, the latter eventually comprising over three-quarters of choices in both treatments. In general, the patterns of individual and group behavior observed in Stage 1 qualitatively match typical findings in the literature: First, effort levels decrease over rounds, and second, following an initial period of miscoordination, groups tend to coordinate on low-efficiency equilibria, mostly the least efficient one.

Turning to Stage 2, Figure 1 shows that the average effort jumps upwards to 4.5 in Punishment and to 5.0 in Disapproval in the restart round 9, almost reaching 


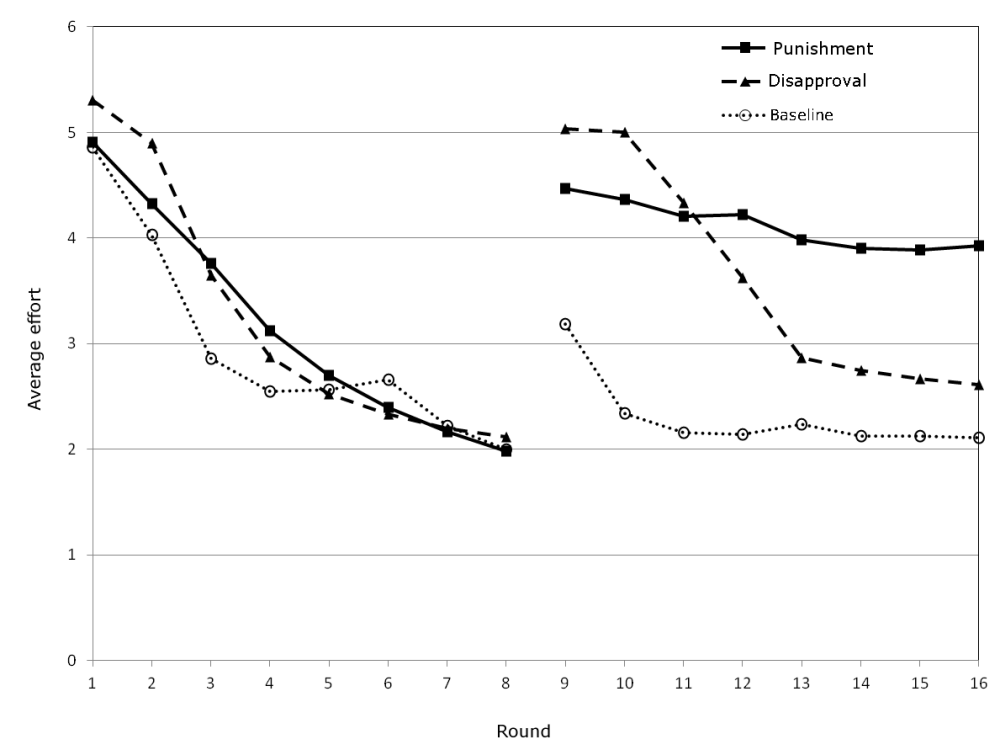

Figure 1: Average effort per round and treatment

the initial round 1 levels. Subsequently, the Punishment effort falls slowly over time to reach 3.9 in the final round 16, whereas the Disapproval effort falls much faster from round 11 onwards to eventually reach 2.6. These dynamics can be compared with the pure restart effect in Baseline where the average effort jumps up much less in round 9 and then almost immediately falls back to the lowest level of 2.1 reached at the end of Stage 1. These results also hold for average minimum effort. For Baseline, Figure 2 indicates a small positive restart effect for average minimum effort that remains at 2.1 throughout Stage 2, except for a slight drop in the final round. In Punishment, minimum effort rises markedly to eventually reach 3.7, whereas in Disapproval minimum effort increases only mildly for several rounds, thereafter remaining around 2.6.

At the end of Stage 2, average efforts are just above the respective average minimum efforts in all treatments, implying that groups mostly manage to coordinate on particular equilibria. Thus Figure 3 conveniently portrays not only aggregate effort-choice distributions but also approximately the percentage of groups coordinating on particular equilibria in the final rounds of each stage. The effort-choice distributions in Figure 3 broadly confirm the finding that the attained equilibria overall involve more efficient effort levels in Punishment compared to Disapproval and especially to Baseline. In particular, there is a much stronger efficiency gain in 


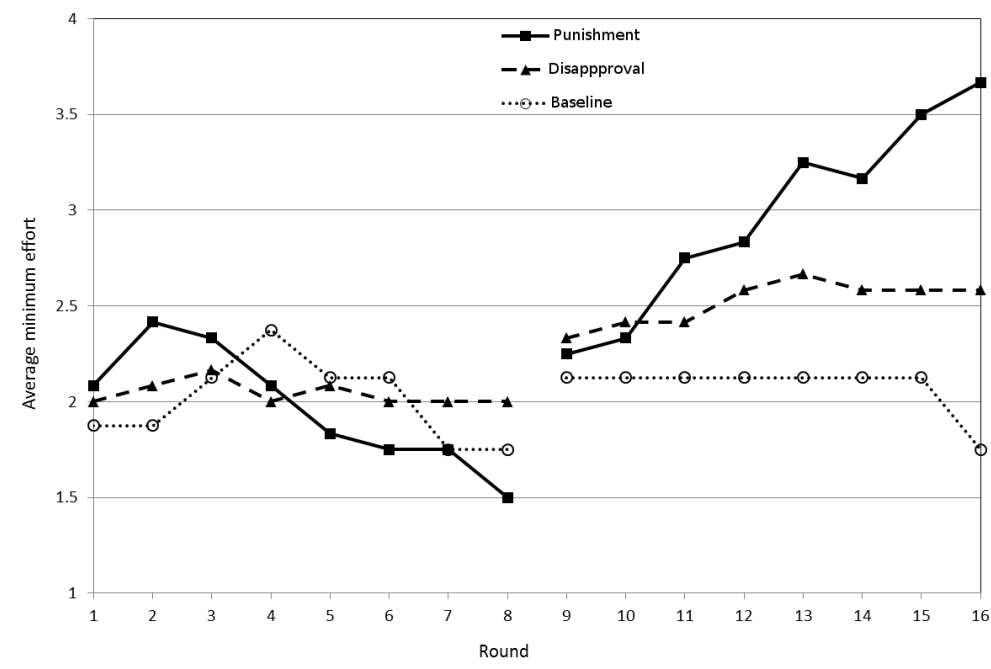

Figure 2: Average minimum effort in groups per round and treatment

Punishment where the percentage of subjects choosing the two highest effort levels rises from 2 to 36 percent between the last two rounds of each stage, while the percentage choosing the two lowest effort levels falls from 70 to 33 percent (compared with a decrease from 80 to 72 percent in Disapproval).

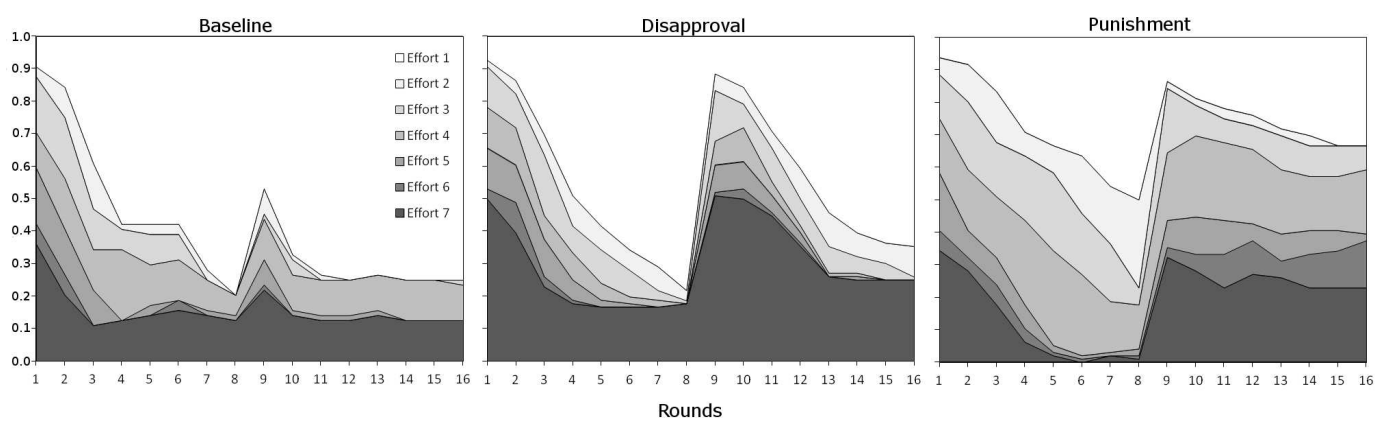

Figure 3: Distribution of effort choices per round and treatment

These patterns are confirmed by statistical tests. We first compare effort choices by the Mann-Whitney $U$ test applied to average efforts at the group level. ${ }^{3}$ In Stage 1, the across-treatment differences were not significant either overall or in individual rounds, reflecting the identical design setup across treatments. In Stage 2, groups' average efforts were significantly higher in Punishment compared to Baseline both overall $(p<0.05)$ and in the first six rounds $(p<0.05$ in rounds 10-12 and

\footnotetext{
${ }^{3}$ Depending on the type of comparison, groups' average efforts in a given treatment are calculated for each stage or each round. In round 1, we apply the test directly to effort choices since these are independent unlike in subsequent rounds.
} 
14; $p<0.10$ otherwise), and also significantly higher in Disapproval compared to Baseline both overall $(p<0.05)$ and in the first five rounds $(p<0.05$ in round 10; $p<0.10$ otherwise). The differences between Punishment and Disapproval, though substantial, were not statistically significant. Parametric tests provide a similar degree of support for the across-treatment differences: Wald tests from ordered probit estimation indicate that effort does not significantly differ across treatments in Stage 1 overall, nor in each round. ${ }^{4}$ As an exception, effort in round 1 is significantly higher in Disapproval compared to both Punishment and Baseline $(p<0.10)$. In Stage 2, effort is higher in Punishment compared to Baseline both overall $(p<0.10)$ and in the first five rounds ( $p<0.05$ in round 10; $p<0.10$ otherwise). Effort is also higher in Disapproval compared to Baseline in the first three rounds $(p<0.01$ in round $10 ; p<0.05$ otherwise). Finally, turning to minimum effort instead of average effort, groups' minimum efforts do not significantly differ across treatments in Stage 1 either overall or in individual rounds, according to both the Mann-Whitney $U$ test and the Wald test. ${ }^{5}$ Confirming the observation in Figure 2, the effect of punishment opportunities is most pronounced towards the end of Stage 2. For both tests, minimum effort is significantly higher in Punishment compared to Baseline in the final round $16(p<0.10)$.

In sum, Stage 2 generates across-treatment efficiency differences in the posited direction. From about the same aggregate starting point at the end of Stage 1, the efficiency gains in Stage 2 are initially slightly larger in Disapproval than in Punishment - perhaps reflecting subjects' initial hopes of the effectiveness of the cheap-talk communication device - but these hopes fade rather quickly and the efficiency gains are eventually considerably larger in Punishment than in Disapproval. Except for a small positive restart effect, Stage 2 brings about no efficiency gains in Baseline.

\footnotetext{
${ }^{4}$ We regress effort choices on treatment dummies interacted with a stage dummy or round dummies (for across-treatment comparison at the stage level or the round level, respectively). The estimations are based on a panel of 256 subjects with 16 rounds of effort choices each. We use the cluster-robust estimator of variance allowing for intra-group correlation of effort choices. The number of clusters (i.e., groups) seems sufficient given the perfectly balanced cluster sizes (e.g., Ktezdi (2004); Rogers (1993)). The results are unaffected if including a second level of clustering at the subject level, or instead including group and individual-level random effects. Wald tests from ordered logit models and $t$-tests from linear probability models yield very similar results in terms of significance levels, as do separate estimations for round 1 performed without group clustering (since effort choices are independent).

${ }^{5}$ We regress groups' minimum efforts on treatment dummies interacted with a stage dummy or round dummies. The estimations are based on a panel of 32 groups with 16 rounds of minimum efforts each. As above, we use the cluster-robust estimator of variance allowing for intra-group correlation of observations. The results are unaffected if one includes instead group-level random effects. Other estimation details are identical to the estimation for effort choices.
} 
In order to test the robustness of these effects, we next compare between-stage changes in behavior across treatments. The results are provided in Table 2 . The first row (i.e., block of results) displays effort changes and their statistical significance between Stages 1 and 2, both overall and for each round-pairs (i.e., rounds 1 and 9, 2 and 10, etc.). From the same effort level of about 3 in Stage 1, the average effort in Stage 2 increases by 0.95 (30 percent) in Punishment and 0.38 (12 percent) in Disapproval, whereas it decreases by 0.66 (22 percent) in Baseline. The overall efficiency gain in Punishment as well as the overall efficiency loss in Baseline are significant by both the ordered probit Wald test described above and the Wilcoxon signed-rank test applied to groups' average efforts. Punishment features an initial average-effort decrease in the first round-pair followed by increases that become larger over time. The effort increases in the last five round-pairs are significant. A pattern of initial average-effort decreases followed by increases also occurs in Disapproval, but the increases fade after the fifth round-pair and subsequently remain much smaller than in Punishment. Moreover, changes are not significant in any round-pair. Baseline generally features average-effort decreases of declining magnitude (except for a small increase in the last round-pair) which are significant in the first three round-pairs and in the fifth and sixth round-pairs.

The overall picture is one of rising efficiency gains in Punishment which increasingly outweigh those in Disapproval, and of efficiency losses in Baseline. The Wald tests for treatment effect presented in the first block of Table 2 show that the positive treatment effect between Punishment and Baseline is significant both overall (see column titled "Stage 1-2") and in each round-pair, while the positive treatment effect between Disapproval and Baseline is significant overall and in the first three roundpairs. Last, the positive treatment effect between Punishment and Disapproval is weakly significant in the last two round-pairs. ${ }^{6}$

These conclusions remain largely true when focusing instead on the average minimumeffort changes (block 2), on the the fraction of groups with an average effort increase

\footnotetext{
${ }^{6}$ We regress within-subject effort-choice changes on treatment dummies, and their interaction with round-pair dummies whenever performing separate tests for each round-pair. The estimations are based on a panel of 256 subjects with eight effort-choice changes each (i.e., changes between rounds 1 and 9, 2 and 10, etc.). As above, we use the cluster-robust estimator of variance allowing for intra-group correlation of observations. Other estimation details are identical to the estimation for effort choices.
} 


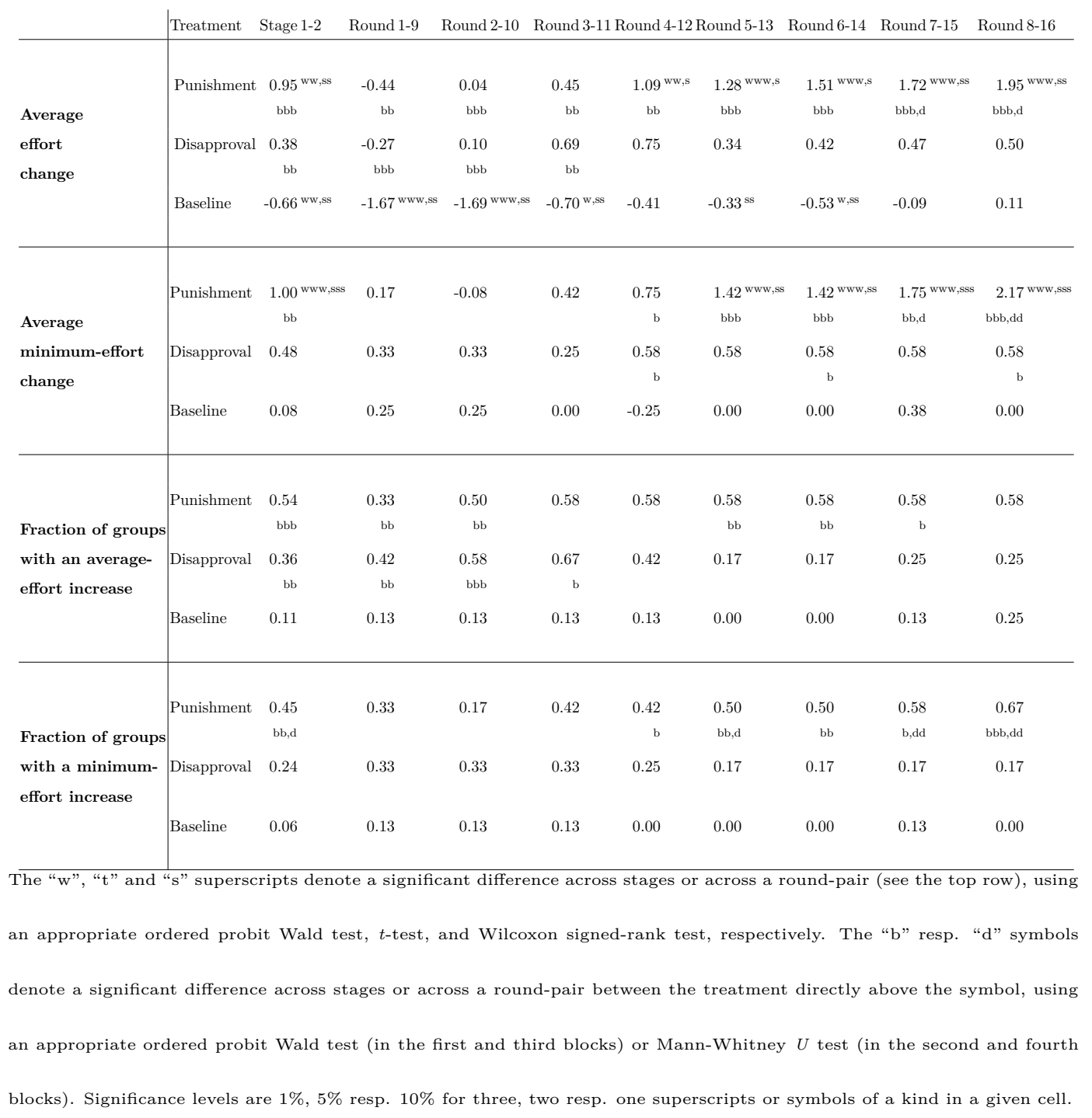

Table 2: Between-stage and between-round effort changes in each treatment

(block 3), or on the fraction of groups with a minimum effort increase (block 4). In most cases, these analyses support the fact that Punishment at the end of Stage 2 leads to a significant increase in efficiency, unparalleled in the other treatments. Disapproval tends to yield significant gains in efficiency only temporarily since these gains seem to vanish and lose significance by the end of Stage 2 .

Overall, the results yield a consistent picture. Baseline replicates the typical findings in the literature on experimental Pareto-ranked games, namely gradual convergence to low-efficiency coordination and a very small and temporary efficiency improvement in the restart stage. Both Disapproval and Punishment bring about substantial efficiency gains following the restart, but only in Punishment does this 
positive effect persist throughout the restart stage and becomes stronger over time in terms of the outcome of the game, i.e., minimum effort. The strong positive effect of Punishment vis-a-vis the other treatments is evident not only in the plain between-subject comparison in Stage 2, but especially in the tighter within-subject and within-group comparison of efficiency gains between stages. Voluntary monetary sanctions in Punishment hence seem capable of persistently increasing coordination efficiency levels, even in groups that previously converged to very inefficient coordination outcomes. By contrast, the effect of ex post cheap talk in Disapproval does not seem strong enough to stabilize coordination at a substantially higher efficiency level compared to Baseline.

\subsection{Punishment and disapproval behavior}

We next ask what kind of punishment behavior, and perhaps to a lesser extent what kind of disapproval behavior, may drive the observed coordination outcomes. In Punishment, 657 points are assigned overall - 80 percent in the first half of Stage 2 - inflicting a total cost of 65.7 euros on the punishers and 131.4 euros on the punished (i.e., about 9 percent of punishment points were not actually implemented because they would have decreased a punished subject's round payoff to below zero). Figure 4 shows that the percentages of punishers and punished start off at 44 and 53 percent, respectively, and both percentages decline gradually to just nine percent in the final round. Each punisher initially assigns four points on average. This figure declines gradually to below two points in the penultimate round and then jumps back to four points in the final round.

In Disapproval, 12,766 points are assigned overall - 45 percent in the first half of Stage 2 - which is almost 20 times higher than in Punishment. The percentage of disapprovers starts off at 73 percent and is still at 54 percent at the end, while the percentage of disapproved begins at 61 percent and eventually reaches 82 percent. Each disapprover initially assigns 17 points on average, and this figure steadily rises to eventually reach 37 points, rather close to the maximum of 42 points. Thus disapproval is much more widespread than punishment and the gap widens over time. 


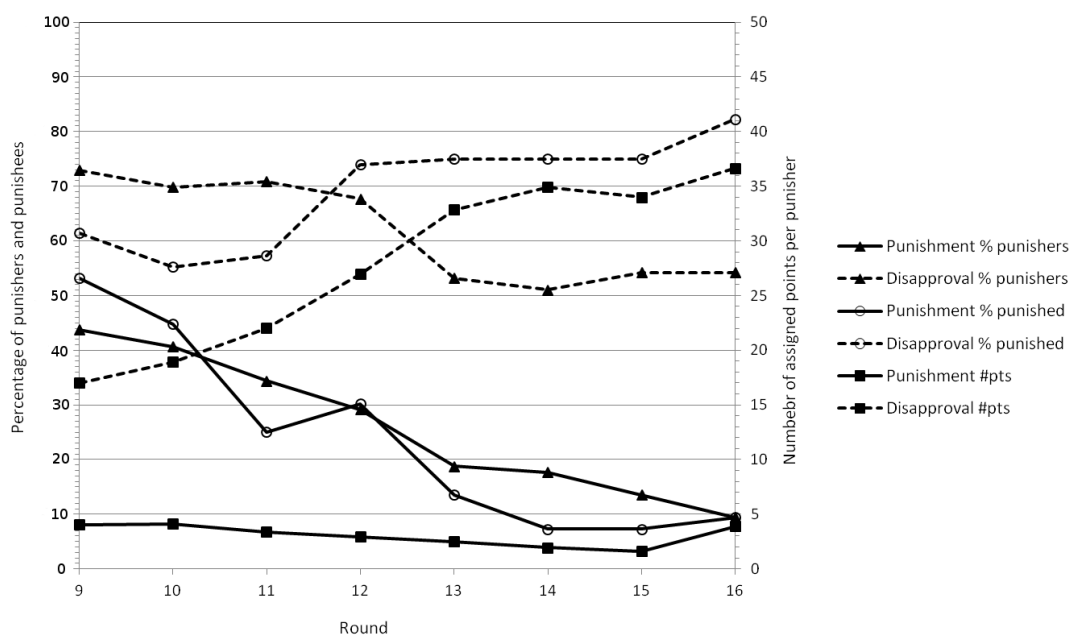

Figure 4: Punishment and disapproval points assignment

\begin{tabular}{|c|c|c|c|c|c|c|c|c|c|c|c|c|c|c|c|c|c|}
\hline & & \multicolumn{7}{|c|}{ punished subject's effort level } & Row & \multicolumn{7}{|c|}{ disapproved subject's effort level } & \multirow{2}{*}{$\begin{array}{l}\text { Row } \\
\text { total }\end{array}$} \\
\hline & & 1 & 2 & 3 & 4 & 5 & 6 & 7 & total & 1 & 2 & 3 & 4 & 5 & 6 & 7 & \\
\hline \multirow{3}{*}{ punisher's or } & 1 & 3.2 & 0 & 0 & 0 & 0 & 0 & 1.1 & 4.7 & 49.9 & 2.8 & 1.6 & 0.3 & 0.4 & 0 & 0.4 & 55.5 \\
\hline & 2 & 0 & 0 & 0 & 0 & 0 & 0 & 0 & 0 & 6.8 & 3.2 & 1.5 & 0.3 & 0.1 & 0 & 0.2 & 12.0 \\
\hline & 3 & 3.7 & 4.6 & 0.8 & 0.3 & 0 & 0 & 0 & 9.3 & 3.4 & 1.7 & 2.0 & 0.7 & 0.5 & 0.0 & 0.3 & 8.6 \\
\hline \multirow[t]{2}{*}{ disapprover's } & 4 & 5.5 & 2.9 & 5.0 & 0.8 & 0.2 & 0.2 & 0.9 & 15.4 & 1.5 & 0.6 & 0.9 & 0.2 & 0.1 & 0 & 0.1 & 3.4 \\
\hline & 5 & 3.5 & 1.5 & 2.0 & 3.0 & 0.2 & 0.5 & 0 & 10.7 & 1.7 & 0.6 & 1.4 & 0.7 & 0.2 & 0 & 0 & 4.6 \\
\hline \multirow[t]{2}{*}{ effort level } & 6 & 1.5 & 0.6 & 1.4 & 5.3 & 4.0 & 0.2 & 0.2 & 13.1 & 0 & 0 & 0.1 & 0.2 & 0.1 & 0 & 0 & 0.5 \\
\hline & 7 & 19.6 & 1.2 & 6.5 & 11.9 & 2.9 & 3.5 & 1.2 & 46.9 & 6.2 & 1.0 & 3.7 & 1.9 & 1.4 & 0.8 & 0.3 & 15.3 \\
\hline Col. Total & & 37.0 & 10.8 & 15.7 & 21.8 & 7.2 & 4.3 & 3.3 & $657 \mathrm{pts}$ & 69.6 & 9.9 & 11.7 & 4.3 & 2.8 & 0.9 & 1.3 & $12,766 \mathrm{pt}$ \\
\hline
\end{tabular}

Table 3: Percentage of points assigned in Punishment and Disapproval

Table 3 displays the distribution of punishment and disapproval points, aggregated across Stage 2, conditional on effort choices of the subjects by whom and to whom the points were assigned in any given round. In Punishment, punishers assign 90 percent of points to group members with a lower effort than theirs, i.e., the assigned points appear below the main diagonal. The most populated bottom-left cell contains points of punishers with effort level 7 assigned to subjects with effort level 1. As could be expected, punishment points are mainly targeted at "shirkers" (i.e., subjects with the lowest effort in the group). The second-order public good problem is typically present since most points are assigned by few group members (not always those with the highest effort); other members seemingly prefer to instead signal their desire to raise efficiency by choosing a high effort level.

In Disapproval, only 35 percent of points are assigned by disapprovers to group members with a lower effort than theirs. The main reason for this much lower 
percentage compared to Punishment is that half of all disapproval points are assigned from shirkers to other shirkers choosing the same effort level 1. These points are assigned in two-thirds of Disapproval groups that converge to the least efficient equilibrium, mostly in the last rounds when the groups had already reached or almost reached the equilibrium. Even if one leaves out this rather special category of disapproval behavior, disapproval points are generally less consistently targeted at shirkers compared to Punishment, especially towards the end where group coordination outcomes are more or less settled.

\subsection{Welfare}

The fact that Punishment leads to higher efficiency does not guarantee that welfare - defined here in a restricted way as a subject's total payoff - is improved: the losses due to punishment (to both parties involved) may exceed efficiency gains in the stage game. Figure 5 shows for each treatment the evolution of average payoff as a fraction of the maximum achievable payoff (i.e., 2.60 euros per subject achieved if everyone chose the highest effort level 7 in a given round). In Punishment, we distinguish between payoff in the stage game and profit, i.e., the payoff minus punishment costs (more precisely, the cost of punishing and being punished). For the other treatments, payoff and profit are obviously equal. Starting off at about 40 percent in all treatments, the average payoff rises throughout Stage 1 to eventually reach 60 percent in Disapproval, 58 in Baseline and 54 in Punishment. The upward trend and the magnitude of the average payoff for all treatments reflect the improving individual coordination on mostly inefficient equilibria.

In Stage 2, the average payoff in Baseline initially rises slightly above the level reached at the end of Stage 1 and then stays at that level. This reflects that individual and collective outcomes in Baseline remain at, or quickly return to those attained at the end of Stage 1. The average payoff in Punishment and Disapproval initially drops substantially to slightly above the initial round 1 level, subsequently rising steadily and surpassing the Baseline average payoff in the second half of Stage 2. The initial drop is due to the extensive attempts in both treatments to raise efficiency, with negative consequences for individual coordination outcomes. The subsequent upward trend in average payoff stems from the gradual individual 


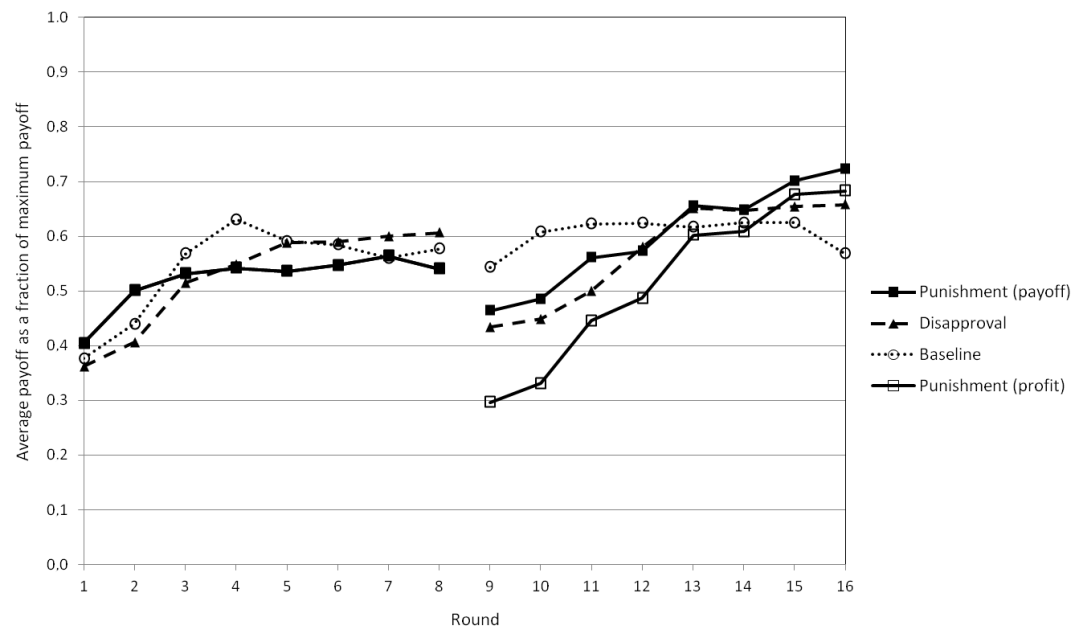

Figure 5: Payoffs and profits per round and treatment

coordination improvements as well as from about half the groups in Punishment and two groups in Disapproval improving their collective coordination outcomes.

Figure 5 further shows that at the beginning of Stage 2, the average profit in Punishment is only at 30 percent of the maximum achievable payoff and 17 percentage points below the average payoff. Clearly, the welfare consequences of punishment are considerable. They seem to decrease over time as both the average payoff and average profit eventually reach about 70 percent, which is higher compared to Disapproval and Baseline. Nonetheless, the across-treatment welfare differences at the end of Stage 2 are minor compared to the efficiency (i.e., effort) differences observed in Figures 1 and 2. Indeed, the Mann-Whitney $U$ test suggests that average payoff is significantly higher in Punishment compared to Baseline in the final round 16 $(p<0.05)$, while other across-treatment differences are not significant. When including the cost of punishment, profit is significantly lower in Punishment compared to Baseline in the first two rounds of Stage $2(p<0.10$ in round $9 ; p<0.01$ in round 10) but significantly higher in the final round $16(p<0.10)$. Results from $t$-tests in OLS estimation lead to similar conclusions. ${ }^{7}$

\footnotetext{
${ }^{7}$ As for the effort-choice comparisons in section 3.2, we regress individual payoffs on treatment dummies interacted with a stage dummy or round dummies. The estimations are based on a panel of 256 subjects with 16 rounds of payoffs each. As above, we use the cluster-robust estimator of variance allowing for intra-group correlation of observations. Other estimation details are identical to the estimation for effort choice changes.
} 


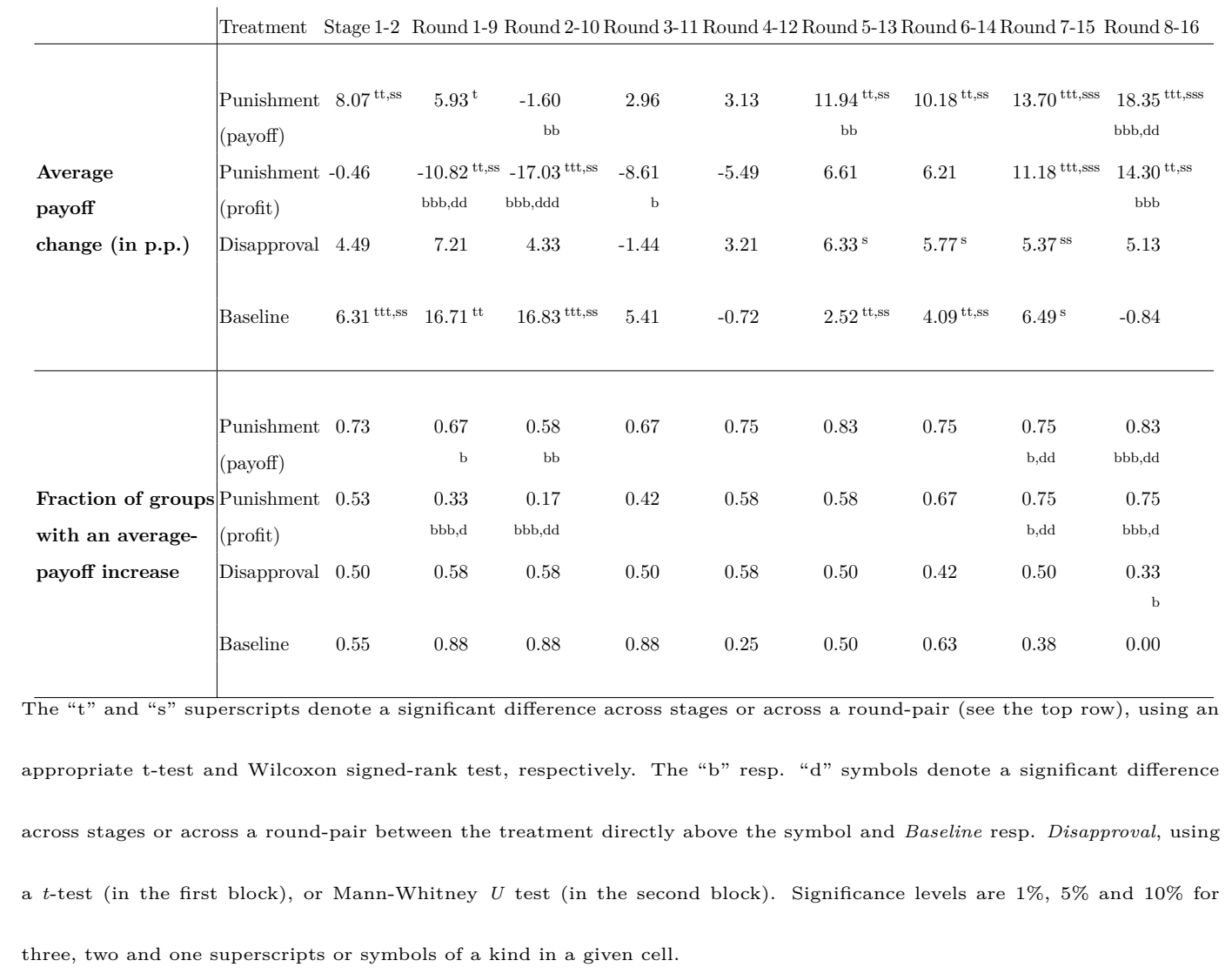

Table 4: Between-stage and between-round welfare changes in each treatment

The first block of results in Table 4 displays payoff changes (i.e., welfare gains and losses) between Stages 1 and 2. From about the same level of 52-54 percent of the maximum achievable payoff in Stage 1, average payoff in Stage 2 increases by 8.07 percentage points (0.21 euros) in Punishment, 4.49 percentage points (0.12 euro) in Disapproval, and 6.31 percentage points (0.16 euro) in Baseline. The overall welfare gains in Punishment and Baseline are significant by both the $t$-test described above and the Wilcoxon signed-rank test. In Punishment, the overall profit (including punishment costs) decreases insignificantly by 0.5 percentage points $(0.01$ euro). Because of high punishment costs, Punishment initially features relatively large profit decreases that are significant in the first two round-pairs. The pattern eventually reverses: In the last four round-pairs, the welfare gains in Punishment reach over 10 percentage points and are significant by the $t$-test as well as the Wilcoxon signed-rank test applied to groups' average payoffs. Disapproval generally features small welfare gains throughout, while Baseline features large and significant welfare gains in the first two round-pairs. 
The second block in Table 4 complements the first one by displaying the fraction of groups with an average payoff increase (i.e., welfare gain) between stages. The figures tend to confirm the general picture from the first block. Initially, the treatment effect between Punishment and Baseline and between Punishment and Disapproval is significantly negative, at least in the first two round-pairs. However, in the last two round-pairs, the welfare gains are significantly higher in Punishment.

\section{Concluding remarks}

On a general note, our data reveal that, first, Punishment fosters efficiency in a robust and stable way, both in comparison to Stage 1 and to the other treatments in Stage 2, whereas Disapproval seems to have only a transient and limited effect. Second, this seems to be achieved by a rather substantial initial incidence of voluntary sanctions imposed mainly by high-effort players on low-effort ones. Third, the efficiency gains associated with introducing the sanctioning mechanism are initially negative (partly due to the high punishment costs) but ultimately turn out significantly positive. Hence after the initial episode of miscoordination and adjustment to the new conditions, and "coordination costs" incurred by using the sanctions, the sanctions can substantially improve coordination outcomes.

Our findings raise several issues. First, our results suggest that communication - more precisely, ex post disapproval communication - may not be a strong enough efficiency-enhancing coordination device in particularly adverse conditions, such as when there are large groups, anonymous actions, or a history of inefficient coordination. By contrast, punishment opportunities seem more powerful under the same conditions, despite the fact that they imply a monetary cost to their user, unlike cost-free disapproval. In this sense, our findings resemble the effect of punishment found in cooperation games, thus possibly contributing to an explanation of why efficient coordination arises in real economic settings.

A related methodological point would be that it may generally be more appropriate to test the (relative) power of efficiency-enhancing coordination devices after allowing for a history of low-efficiency coordination, as has been demonstrated in cooperation settings (e.g., Fehr and Gaechter, 2000). In coordination settings such as 
ours, the reasons for doing so are even more pronounced due to a possibly stronger path-dependence typically observed in coordination games. Without initially allowing for a low-efficiency coordination, a rather mild initial nudge provided by an otherwise weak coordination device may be sufficient to improve efficiency and to sustain it. Hence the relative strength of different mechanisms may be hard to assess, since small and not easily observed differences in initial conditions, e.g. subject's expectations, may have a great empirical impact.

Finally, we suggest a future line of research about the effect of punishment opportunities in more general coordination games, i.e., not Pareto-ranked coordination games. If the motive for punishment is purely instrumental (inducing others to raise their effort) or based on group-level reciprocity, it is possible that sanctioning opportunities may improve the stability of an arbitrary equilibrium: if players who occasionally or randomly deviate from an equilibrium face retaliation and its consequences, such deviations may become less frequent. Deviations, even if only erroneous, are made much more costly than in the absence of such punishment. This may have interesting consequences for the formation of conventions or social norms and their decentralized enforcement - a question critical to economics in many respects (Knack and Keefer, 1997) - even though the roots of their transgression may not actually be malevolent or ill-intended. The specific conditions under which informal sanctions help coordination at a broader level are of course an empirical question.

\section{References}

Anderson, C., and L. Putterman (2006): "Do non-strategic sanctions obey the law of demand? The demand for punishment in the voluntary contribution mechanism," Games and Economic Behavior, 54(1), 1-24.

Becker, G., And K. Murphy (1992): "The division of labor, coordination costs, and knowledge," The Quarterly Journal of Economics, 107(8), 1137-1160.

Blume, A., And A. Ortmann (2007): "The effects of costless pre-play communication: Experimental evidence from games with Pareto-ranked equilibria," Journal of Economic Theory, 132, 274-290. 
Brandts, J., And D. Cooper (2006): "A change would do you good: An experimental study on how to overcome coordination failure in organizations," American Economic Review, 96(3), 669-693.

(2007): "It's what you say, not what you pay: An experimental study of manager-employee relationships in overcoming coordination failure," Journal of the European Economic Association, 5(6), 1223-1268.

Camerer, C. F., And M. Knez (1994): "Creating 'expectational assets' in the laboratory: 'Weakest-link' coordination games," Strategic Management Journal, 15, 109-109.

Devetag, G., And A. Ortmann (2007): "When and why? A critical survey on coordination failure in the laboratory," Experimental Economics, 10(3), 331-344.

Dugar, S. (2010): "Nonmonetary sanctions and rewards in an experimental coordination game," Journal of Economic Behavior and Organization, 73(3), 377-386.

Engelmann, D., And H.-T. Normann (2010): "Maximum effort in the minimumeffort game," Experimental Economics, 13(3), 249-259.

Falk, A., E. Fehr, And U. Fischbacher (2008): "Testing theories of fairness: Intentions matter," Games and Economic Behavior, 62(1), 287-303.

Fatas, E., T. Neugebauer, and J. Perote (2006): "Within-team competition in the minimum effort coordination game," Pacific Economic Review, 11(2), 247266.

Fehr, E., and S. Gaechter (2000): "Cooperation and punishment in public goods experiments," American Economic Review, 90, 980-994.

Fischbacher, U. (2007): "z-Tree: Zurich toolbox for ready-made economic experiments.," Experimental Economics, 10, 171-178.

Goeree, J. K., and C. A. Holt (2005): “An experimental study of costly coordination," Games and Economic Behavior, 51(2), 349-364.

GreineR, B. (2004): "An online recruitment system for economic experiments," in Forschung und wissenschaftliches Rechnen 2003, ed. by K. Kremer, and V. Macho. Göttingen : Ges. für Wiss. Datenverarbeitung,. 
Horwitz, A. (1990): The logic of social control. New York : Plenum Press.

KŤEzDI, G. (2004): "Robust standard error estimation in fixed-effects panel models.," Hungarian Statistical Review Special, 9, 96-116.

Knack, S., And P. Keefer (1997): "Does social capital have an economic payoff? A cross-country investigation," The Quarterly Journal of Economics, 112(4), $1251-1288$.

Masclet, D., C. Noussair, S. Tucker, and M.-C. Villeval (2003): "Monetary and nonmonetary punishment in the voluntary contributions mechanism," American Economic Review, 93, 366-380.

Ostrom, E., J. Walker, And R. Gardner (1992): "Covenants with and without a sword: Self governance is possible," American Political Science Review, 86, 404417.

Rogers, W. H. (1993): "sg17: Regression standard errors in clustered samples.," Stata Technical Bulletin, 13, 19-23.

Romero, J. (forthcoming): "The effect of hysteresis on equilibrium selection in coordination games," Journal of Economic Organization and Behavior.

Van Huyck, J., R. Battalio, and R. Beil (1990): "Tacit coordination games, strategic uncertainty, and coordination failure," American Economic Review, 80(1), 234-248.

Van Huyck, J., R. Battalio, and F. Rankin (2007): "Evidence on learning in coordination games," Experimental Economics, 10(3), 205-220. 


\section{Working Paper Series}

ISSN 1211-3298

Registration No. (Ministry of Culture): E 19443

Individual researchers, as well as the on-line and printed versions of the CERGE-EI Working Papers (including their dissemination) were supported from institutional support RVO 67985998 from Economics Institute of the ASCR, v. v. i.

Specific research support and/or other grants the researchers/publications benefited from are acknowledged at the beginning of the Paper.

(c) Fabrice Le Lec, Ondřej Rydval, and Astrid Matthey, 2014

All rights reserved. No part of this publication may be reproduced, stored in a retrieval system or transmitted in any form or by any means, electronic, mechanical or photocopying, recording, or otherwise without the prior permission of the publisher.

Published by

Charles University in Prague, Center for Economic Research and Graduate Education (CERGE) and

Economics Institute of the ASCR, v. v. i. (EI)

CERGE-El, Politických vězňů 7, 11121 Prague 1, tel.: +420 224005 153, Czech Republic.

Printed by CERGE-EI, Prague

Subscription: CERGE-EI homepage: http://www.cerge-ei.cz

Phone: + 420224005153

Email: office@cerge-ei.cz

Web: http://www.cerge-ei.cz

Editor: Marek Kapička

The paper is available online at http://www.cerge-ei.cz/publications/working_papers/.

ISBN 978-80-7343-331-4 (Univerzita Karlova. Centrum pro ekonomický výzkum a doktorské studium)

ISBN 978-80-7344-323-8 (Akademie věd České republiky. Národohospodářský ústav) 
CERGE-EI

P.O.BOX 882

Politických vězňů 7

11121 Praha 1

Czech Republic http://www.cerge-ei.cz 